Original Research Paper

\title{
Pengolahan Limbah Kotoran Sapi Menjadi Pupuk Organik untuk Perbaikan Kualitas Lingkungan Desa Seputih Kecamatan Mayang Kabupaten Jember
}

\author{
Ika Purnamasari $^{1}$, Suci Ristiyana ${ }^{1}$, Yagus Wijayanto ${ }^{1}$, Tri Wahyu Saputra ${ }^{1}$

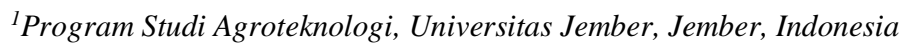

https://doi.org/10.29303/jpmpi.v3i2.1357

Sitasi: Purnamsari, I., Ristiyana, S., Wijayanto, Y \& Saputra, T. W. (2022). Pengolahan Limbah Kotoran Sapi Menjadi Pupuk Organik untuk Perbaikan Kualitas Lingkungan Desa Seputih Kecamatan Mayang Kabupaten Jember. Jurnal Pengabdian Magister Pendidikan IPA, 5(1)

\section{Article history}

Received: 11 Januari 2022

Revised: 01 Februari 2022

Accepted: 07 Februari 2022

*Corresponding Author: Ika Purnamasari, University of Jember, Jember, Indonesia; Email:

ikapurnamasari@unej.ac.id

\begin{abstract}
Seputih Village is one of the villages in Mayang District, Jember Regency. In addition to the agricultural sector, the livestock sector is also the mainstay of the village, namely cattle with almost $70 \%$ of households owning livestock. The high number of cattle in the community causes an increase in the amount of livestock manure produced. One solution that can be applied to reduce this waste is by processing manure into solid organic fertilizer so that the community service program implemented in Seputih Village is the manufacture of solid organic fertilizer from cow dung that can be utilized by the community on agricultural land. Activities carried out to achieve the objectives include coordination meetings of the lecturer team with village heads, farmers and ranchers; potential survey; training on the manufacture of solid organic fertilizers as well as monitoring and evaluation. The community service activity was enthusiastically welcomed. The community directly received information on the importance of handling cow dung waste and had experience in making organic fertilizer workshops. Solid organic fertilizer can be used after two weeks of the fermentation process.
\end{abstract}

Keywords: Cow Manure; Organic Fertilizer; Environmental Quality; Community Service;

\section{Pendahuluan}

D esa Seputih merupakan salah satu desa di Kecamatan Mayang Kabupaten Jember yang berjarak $32 \mathrm{Km}$ dari pusat kota dan berada pada bagian wilayah utara. Desa Seputih terdiri dari enam Dusun antara lain Dusun Krajan, Pandian, Sumberjeding, Sumberwadung, Tetelan, dan Dusun Wetan Kali. Kondisi geografis yang mendukung seperti kondisi tanah, iklim, kebudayaan masyarakat lokal dengan mayoritas sebagai petani menjadikan wilayah Seputih memiliki keunggulan di bidang pertanian terutama tanaman pangan seperti padi, jagung, kedelai dan tanaman perkebunan seperti tembakau. Potensi lain yang juga mampu menjadi penunjang perekonomian dari Desa Seputih adalah peternakan. Mayoritas masyarakat Desa Seputih memiliki sapi, sekitar hampir $70 \%$ kepala keluarga memelihara sapi dengan jumlah 1-2 sapi per KK. Hal ini menjadikan Desa Seputih sebagai salah satu penyumbang ternak sapi terbesar di Kabupaten Jember.

Masyarakat Desa Seputih terutama Dusun Krajan mayoritas sebagai peternak sapi dengan kondisi kandang yang saling berdekatan antar rumah warga. Hal tersebut menyebabkan pemukiman menjadi lebih padat dan berdekatan dengan kandang sapi. Kotoran ternak yang dihasilkan langsung dibuang ke saluran irigasi 
lahan pertanian warga. Kondisi ini menyebabkan ketika terjadi hujan dapat mencemari perumahan warga sekitar dan mengeluarkan bau tidak sedap. Peternak memilih untuk membuang kotoran sapi langsung ke saluran irigasi dikarenakan tidak terdapat lahan pembuangan atau penampungan limbah kotoran ternak sapi. Hal ini juga didukung dengan minimnya pengetahuan masyarakat akan potensi pemanfaatan limbah kotoran ternak tersebut.

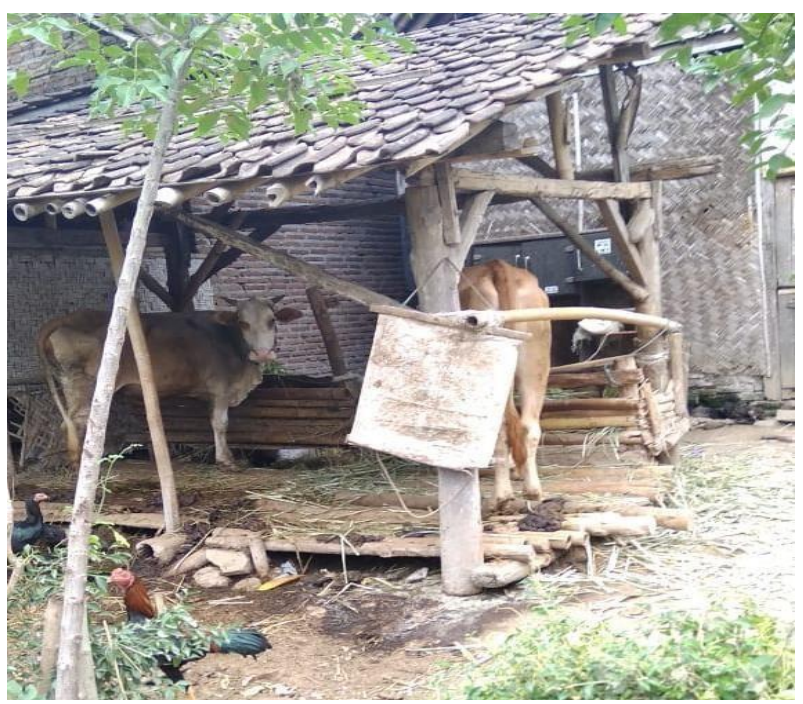

Gambar 1 Peternakan Sapi yang Dimiliki Warga Desa Seputih

Tim program pengabdian dosen pemula Universitas Jember telah melakukan diskusi dengan Bapak Surya Hasan selaku Koordinator seluruh Kepala Dusun dan perwakilan BPD Dusun Krajan.

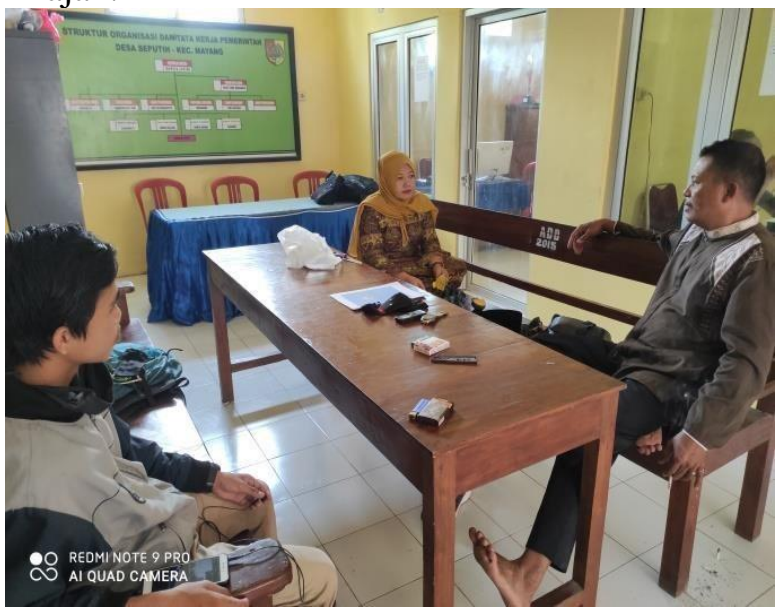

Gambar 2. Sesi Diskusi Tim Pengabdian Dosen Pemula dengan Bapak Hasan SelakuKoordinator
Kepala Dusun Desa Seputih dan Kasun Tetelan.

Berdasarkan hasil diskusi disampaikan bahwa terdapat permasalahan yang dihadapi terkait dengan peternakan sapi berupa banyak limbah kotoran ternak sapi baik limbah padat maupun cair yang dibuang sembarangan. Hal tersebut tentunya dapat menyebabkan pencemaran lingkungan dan mengganggu aktivitas masyarakat. Kondisi ini juga diperparah dengan banyaknya limbah kotoran sapi pada saluran irigasi pertanian sehingga dapat mengganggu distribusi air ke lahan petani. Oleh sebab itu, dibutuhkan suatu konsep manajemen pengelolaan limbah kotoran ternak sapi melalui kegiatan program pengabdian masyarakat. Beliau menyambut baik tim pengabdian dan mendukung program-program dari pihak akademisi maupun Universitas terkait upaya pengolahan limbah kotoran sapi. Hal ini diperlukan untuk meningkatkan dampak positif ekonomi, lingkungan maupun sosial budaya di Desa Seputih.

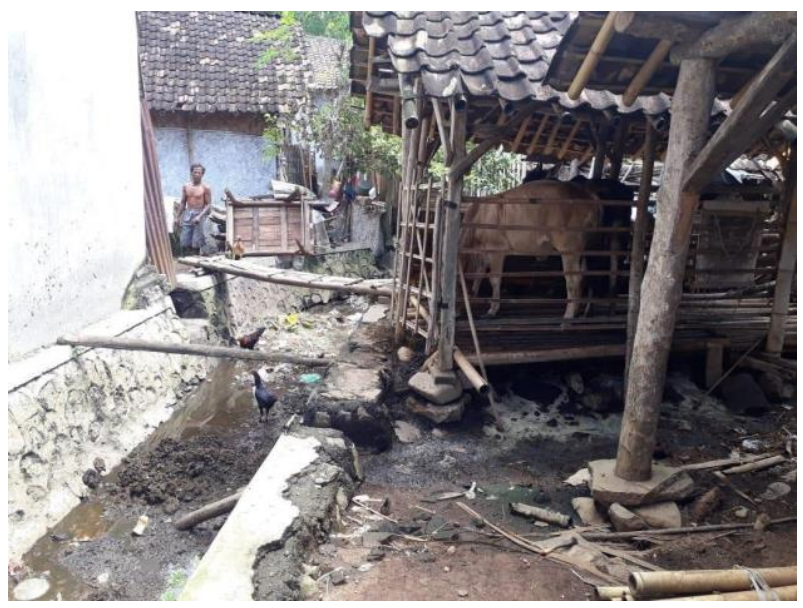

Gambar 3 Tumpukan Limbah Kotoran dan Pakan Sapi pada Saluran Irigasi

\section{Metode}

\subsection{Solusi untuk Pemecahan Masalah}

Pupuk Organik Padat (POP) merupakan sejenis pupuk organik yang dapat berperan sebagai penambah unsur hara pada tanaman. Pada umumnya POP dibuat dari limbah pertanian dan limbah peternakan. Pembuatan POP dilakukan dalam keadaan anaerob. Lama pembuatan POP dipengaruhi oleh kadar air yang terdapat didalamnya. Kandungan unsur hara yang 
terkandung dalam POP antara lain C-organik, N, P, $\mathrm{K}$ yang berperan dalam metabolisme pertumbuhan tanaman. Penggunaan POP lebih dianjurkan dalam sistem pertanian karena pengaplikasiannya yang ramah lingkungan, harganya murah dengan memanfaatkan limbah, dan lebih efisien (Trivana dkk., 2017). Untuk pengabdian yang akan dilakukan kepada masyarakat Seputih adalah pembuatan pupuk organik padat. Hal tersebut didasari dengan banyaknya limbah kotoran sapi di daerah tersebut. Selain itu limbah kotoran sapi di daerah Seputih masih dibuang pada saluran irigasi dan menyebabkan pencemaran lingkungan.

Menurut Windyasmara dkk. (2012), pembuatan pupuk organik padat dapat dilakukan dengan menggunakan kotoran berbagai ternak salah satunya yaitu kotoran sapi. Kotoran sapi mempunyai $\mathrm{C} / \mathrm{N}$ ratio sebesar $23,5 \%$. Rentang rasio $\mathrm{C} / \mathrm{N}$ antara $25-30 \%$ merupakan rentang optimum untuk proses penguraian anaerob. Rasio $\mathrm{C} / \mathrm{N}$ terlalu tinggi, maka nitrogen akan terkonsumsi sangat cepat oleh bakteri-bakteri untuk memenuhi kebutuhan protein dan tidak akan lagi bereaksi dengan sisa karbonnya sedangkan jika rasio $\mathrm{C} / \mathrm{N}$ sangat rendah, nitrogen akan dibebaskan dan terkumpul dalam bentuk $\mathrm{NH} 4 \mathrm{OH}$. Kotoran sapi juga mengandung hemisellulosa sebesar 18,6\%, sellulosa $25,2 \%$, lignin $20,2 \%$, nitrogen $1,67 \%$, fosfat $1,11 \%$ dan kalium sebesar $0,56 \%$.

Limbah peternakan yang dihasilkan oleh aktivitas ternak seperti kotoran akan menimbulkan pencemaran yang memicu protes dari warga sekitar apabila dilakukan pembuangan secara sembarangan. Upaya yang dapat dilakukan untuk mengatasi limbah ternak yang selama ini dianggap mengganggu karena menjadi sumber pencemaran lingkungan perlu ditangani dengan cara yang tepat sehingga dapat memberi manfaat lain berupa keuntungan ekonomis dari penanganan tersebut yaitu dengan pemanfaatan limbah peterakan dengan pembuatan pupuk organik baik padat maupun cair.

Penanganan limbah dengan pembuatan pupuk organik diperlukan bukan saja karena tuntutan akan lingkungan yang nyaman tetapi juga karena pengembangan peternakan mutlak memperhatikan kualitas lingkungan, sehingga keberadaannya tidak menjadi masalah bagi masyarakat di sekitarnya. Pemanfaatan limbah ternak dengan melakukan pembuatan pupuk organik merupakan bentuk upaya pemanfaata energi yang sangat menguntungkan bagi kehidupan.
Selain dengan keuntungan ekonomis namun juga untuk mengurangi pencemaran di lingkungan. Rastyanto dkk. (2013), pemanfaatan kotoran ternak dapat dilakukan dengan cara fermentasi dimana hal tersebut akan menguntungkan bagi kegiatan budidaya pertanian. Solusi berupa penerapan metode pembuatan pupuk organik padat ini dijabarkan dalam beberapa hal yaitu:

1. Pupuk organik padat terbuat dari limbah kotoran ternak sapi dan hijauan/coklatan yang kemudian difermentasikan. Pada pengabdian yang akan dilakukan diharapkan dapat meningkatkan perekonomian masyarakat Seputih serta kualitas lingkungan dengan pengolahan limbah kotoran sapi menjadi pupuk organik padat di daerah tersebut.

2. Melatih perwakilan kelompok tani dalam pembuatan pupuk organik padat secara sederhana dari cara pengumpulan bahan, cara pembuatan pupuk organik padat serta sampai dengan pengemasan dan aplikasi untuk tanaman hortikultura.

3. Monitoring dan Evaluasi. Segala kekurangan, kritik dan saran terkait pelaksanaan program pengabdian masyarakat dievaluasi sehingga bisa diambil langkah- langkah perbaikan. Harapannya petani dan peternak Desa Seputih Kecamatan Mayang mampu memproduksi pupuk organik padat secara terus menerus untuk meningkatkan ekonomi masyarakat serta menigkatkan kualitas lingkungan.

\subsection{Tahap Persiapam}

1. Diskusi dan Sosialisasi

Diskusi dan sosialisasi dilakukan antara tim pelaksana program pengabdian masyarakat dengan Koordinator Kepala Dusun, Kepala Desa Kandangtepus, Perwakilan Petani dan perwakilan peternak. Diskusi dimaksudkan untuk mensosialisasikan tentang rencana mengenalkan metode pembuatan pupuk organik padat sebagai alternatif pupuk untuk tanaman hortikultura di Desa Seputih, Kecamatan Mayang.

2. Peninjauan lokasi

Peninjauan lokasi ditujukan untuk menentukan tempat sosialisasi, tempat 
kegiatan pengabdian yang memiliki banyak limbah kotoran ternak sapi yang dibuang ke saluran irigasi lahan pertanian. Selain itu, akan dilakukan peninjauan lokasi yang strategis sebagai tempat masyarakat berkumpul untuk melaksanakan pembuatan pupuk organik padat.

3. Penyediaan sarana dan prasarana.

Menyediakan sarana dan prasarana untuk kegiatan pengabdian pembuatan pupuk organik padat di Desa Seputih. Sarana dalam pembuatan pupuk organik padat meliputi: Bahan

1. Pupuk kandang matang non fementasi / masih murni : (30kg),

2. Media organik hijauan atau coklatan $\mathbf{2}$ sak (20kg) (pilih salah satu) :

- Hijauan : Dedaunan segar, Daun Kipait, Rumput Gajah, Batang Jagung basah

- Coklatan : serbuk kayu, sekam padi, limbah kulit kopi, cocopiet

3. 1 debog pisang ukuran 2 meter

4. 0,5 sak akar sumber PGPR seperti kacang kacangan, akar tanaman jagung, akar rumputgajah, akar rumput putri malu (tanah sekitaran akar jangan dibersihkan)

5. EM4 sebanyak 1 Liter

Alat

1. Terpal / Plastik mulsa

2. Gombor

3. Cangkul

4. Plastik Kemasan

5. Label Produk

\subsection{Tahap Pelaksanaan}

1. Sosialisi dan penyuluhan kepada Petani dan Peternak di Desa Seputih

Sosialisi dilakukan atas dasar kerja sama dengan Kepala Desa Kandangtepus, Kordinator Kepala Dusun, perwakilan petani dan Peternak. Penyampaian materi dilakukan oleh tim pelaksana program mengenai metode pembuatan pupuk organik padat sebagi bentuk pemanfaatan limbah kotoran sapi sehingga bernilai ekonomi dan meningkatkan kualitas lingkungan. Materi sosialisasi yang lainnya adalah pengemasan pupuk organik padat dan aplikasi pupuk organik padat untuk tanaman hortikultura cabai.

2. Pembuatan Pupuk Organik Padat.

Pembuatan Pupuk organik padat kepada masyarakat bertujuan agar termanfaatkannya dan meningkatnya nilai limbah kotoran sapi sehingga tidak menjadi bahan pencemar lingkungan terutama pada saluran-saluran irigasi pertanian. Prosedur pembuatan Pupuk Organik Padat sebagai berikut:

1. Upayakan lokasi pada tempat yang ternaungi atau tidak terkena cahaya matahari penuh

2. Gelar terpal / plastik mulsa sebagai alas

3. Masukkan pupuk kendang, kemudian bahan hijauan / coklatan yang telah dicacah, kemudian masukkan debog pisang yang telah dicacah.

4. Selanjutnya tiap ketebalan tertentu (25$30 \mathrm{~cm}$ ) disemprot EM4 yang telah diencerkanlalu tumpuk bahan lagi, begitu seterusnya.

5. Campurkan semua bahan jadi satu (kohe, hijauan, debog pisang, dan EM4) dan ditambahair hingga 30-40\%, lalu aduk rata.

6. Tutup dengan terpal / mulsa bekas hingga rapat.

7. Fermentasi dilakukan secara anaerob minimal 30 hari, lebih lama lebih baik.

Setelah pencampuran selesai dilaksanakan, kemudian memasukkan pupuk organik kedalam trashbag dan dilakukan fermentasi selama 2-3 minggu (Nasution dkk., 2017). Proses fermentasi tersebut bertujuan untuk meningkatkan kandungan dan unsur hara pada tanah sehingga sifat fisik, kimia, dan biologi tanah (Tabun dkk., 2017). Kriteria pupuk organik padat yang berhasil yaitu perubahan struktur tanah yang semakin remah, gembur, tidak berarima busuk, dan berwarna lebih gelap karena aktivitas mikroorganisme dalam merombak bahan organik (Sahetapy dkk., 2017).

\subsection{Tahap Monitoring dan Evaluasi}

Tahap Monitoring ini dilaksanakan pada setiap kegiatan. Tahap Monitoring atau pengawasan bertujuan untuk melihat perkembangan penerapan program yang dilakukan serta membahas permasalahan dan hambatan yang dihadapi. Melalui program ini, diharapkan petani mendapatkan pengetahuan 
tentang inovasi pembuatan pupuk organik padat dari limbah kotoran sapi. Selain itu, dilaksanakan tahap evaluasi pada akhir kegiatan dengan tujuan untuk mengetahui ketercapaian program yang dilaksanakan sebagai dasar dalam mengembangkan pupuk organik padat dari limbah korotan sapi di masa mendatang dan pembuatan laporan pengabdian.

Adapun indikator capaian dari program pengabdian masyarakat di Desa Seputih Kecamatan Mayang sebagai berikut:

1. Masyarakat mampu memahami peran penting pengelolaan limbah kotoran ternak baik dari sektor lingkungan, ekonomi, maupun sosial.

2. Masyarakat mampu membuat pupuk organik padat dari limbah kotoran ternak sapi.

3. Masyarakat mampu mengaplikasikan pupuk organik padat dari limbah kotoran ternaksapi di lahan pertanian.

4. Masyarakat mampu mendapatkan manfaat dari proses pembuatan pupuk organik padat dari limbah kotoran ternak sapi.

5. Masyarakat mampu melanjutkan program pembuatan pupuk organik padat dari limbah kotoran ternak sapi secara terpadu

\section{Hasil dan Pembahasan}

\subsection{Tahapan Persiapan}

\section{a. Diskusi dan Sosialisasi}

Tim pelaksana program pengabdian melakukan kunjungan kepada Koordinator Kepala Dusun Desa Seputih. Kunjungan ini dilakukan dengan tujuan untuk bersilaturahim dengan pimpinan Desa, berdiskusi terkait permasalahan yang dialami oleh warga Desa Seputih, melakukan sosialisasi rencana kegiatan pengabdian serta menawarkan alternatif solusi bagia permasalahan yang ada. Kegiatan diskusi dan sosialisasi bertempat di rumah Kordiator Kepala Dusun Desa Seputih (Gambar 4).

\section{b. Peninjauan lokasi}

Peninjauan lokasi ditujukan untuk menentukan tempat sosialisasi, tempat kegiatan pengabdian yang memiliki banyak limbah kotoran ternak sapi yang dibuang ke saluran irigasi lahan pertanian. Selain itu, akan dilakukan peninjauan lokasi yang strategis sebagai tempat masyarakat berkumpul untuk melaksanakan pembuatan pupuk organik padat.

\section{c. Koordinasi dengan Tim Pengabdian}

Kegiatan koordinasi dilakukan oleh tim pengabdian yang terdiri ari dosen dan mahasiswa. Kegiatan koordinasi dilakukan secara daring dan menghasilkan beberapa point peting dalam kegiatan pengabdian diantaranya:

1. Segera melakukan pengadaan sarana dan prasarana yang dibutuhkan dalam kegiatan pengabdian.

2. Mempersiapkan kegiatan pengabdian pada masyarakat yang meliputi: Kegiatan akan dilaksanakan di salah satu rumah peternak yang memiliki lahan luas untuk pembuatan Pupuk organik padat, mengundang 20 peternak dan petani dan perangkat Desa Seputih.

3. Menjadwalkan pelaksanaan kegiatan pengabdian pada pekan kedua Bulan Oktober

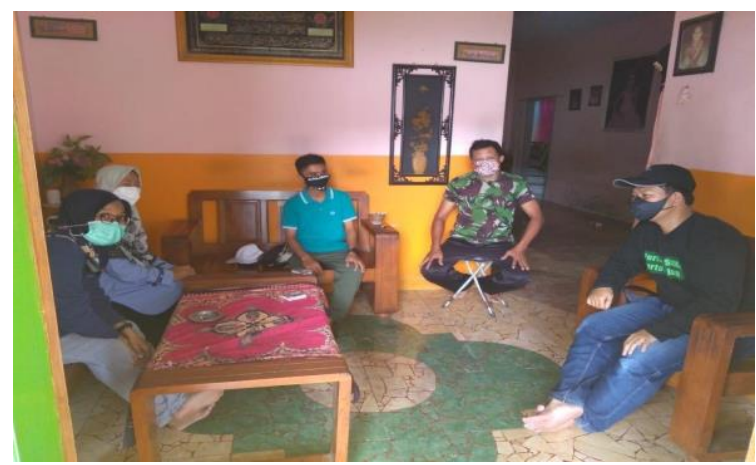

Gambar 4. Kegiatan Diskusi dengan Koordinator RW Desa Seputih

\section{d. Penyediaan sarana dan prasarana}

Telah dilakukan pembelian dan pengadaan terhadap sarana dan prasarana untuk kegiatan pengabdian pembuatan pupuk organik padat di Desa Seputih. Bahan-bahan tersebut diantaranya adalah sebagai berikut:

1. Kotoran sapi matang non fementasi / masih murni :30g

2. Bahan organik coklatan $10 \mathrm{~kg}$ :

- Hijauan : Dedaunan segar, Daun Kipait, Rumput Gajah, Batang Jagung basah

- Coklatan : serbuk kayu, sekam padi, limbah kulit kopi, cocopiet

3. Bahan organik Hijauan 10kg

4. Molase dan EM4 sebanyak 1 Liter 
Bahan hijauan dan coklatan menjadi bahan campuran pupuk organik berbahan utama kotoran sapi. Bahan tersebut ditambahkan untuk memperkaya kandungan nutrisi baik unsur N, P dan $\mathrm{K}$ dalam pupuk. Penggunaan EM4 dimaksudkan untuk mempercepat proses fermentasi pupuk dengan bantuan bakteri berguna. Sedangkan molase bermanfaat untuk menyediakan bahan energi bagi bakteri yang ada.

\subsection{Tahapan Pelaksanaan}

a. Sosialisi dan Penyuluhan kepada Petani dan Peternak di Desa Seputih

Kegiatan sosialisasi dan penyuluhan dilaksanakan pada pukul 12.30-17.00 WIB tanggal 14 Oktober 2021 bertempat di Mushola Desa Seputih. Kegiatan ini dihadiri oleh 30 peserta yang terdiri dari petani dan peternak. Ketua kelompok tani beserta anggota menyambut hangat tim pengabdian pembuatam Pupuk Organik Padat. Proses sosialisasi diawali dengan sambutan panitia penyelenggara yang diwakili oleh M. Reza Abdillah kemudian dilanjutkan dengan sambutan perwakilan pihak Universitas Jember yang disampaikan oleh Bapak Tri Wahyu Saputra S.T.P.,M.Sc dan Perwakilan dari Ketua Kelompk Tani Desa Seputih. Kegiatan inti diisi oleh Ika Purnamasari, S.Si.,M.Si selaku ketua tim dengan memberikan penjelasan urgensi pengelolaan limbah kotoran sapi menjadi pupuk organik padat. Pembuatan pupuk organik padat, selain dapat memperbaiki kualitas linkungan juga dapat meningkatkan pendapatan penunjang perekonomian warga Desa Seputih. Pupuk organik padat berbahan dasar kotoran sapi dengan tambahan hijauan dan coklatan mampu meningkatkan kandungan hara dalam tanah. Setelah penyempaian materi dilakukan diskusi. Diskusi berlangsung dengan dinamis, peseta sangat bersemangat bertanya kepada tim pengabdian baik berkaitan dengan kandungan hara pupuk maupun tatacara pembuatan pupuk.

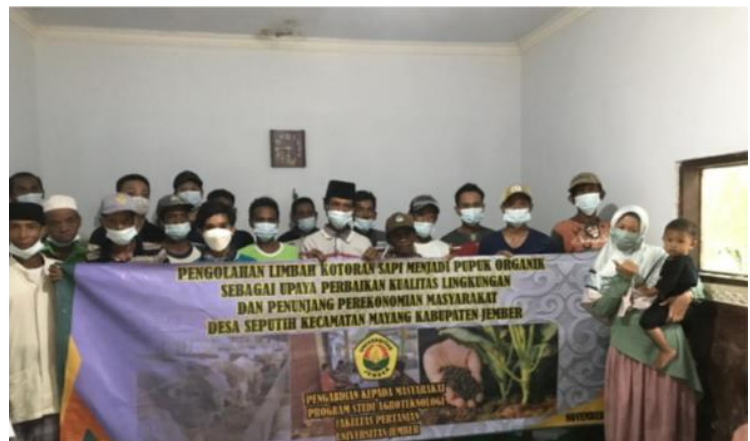

Gambar 5. Kegiatan Sosialisasi dan Penyuluhan pembuatan Pupuk Organik Padat

\section{b. Pembuatan Pupuk Organik Padat}

Pembuatan pupuk organik padat dengan bahan dasar kotoran sapi dibuat dengan beberapa tahapan diantaranya yaitu pencacahan bahan hijauan, pengadukan kotoran sapi, pengadukan bahan coklatan, pengenceran dan pemberian EM4. Rincian kegiatan pembuatan pupuk organik adalah sebagai berikut:

\section{- Pencacahan Bahan Hijauan dan PGPR}

Bahan hijauan yang dibutuhkan untuk pembuatan pupuk organik berjumlah $10 \mathrm{~kg}$ atau $1 / 4$ dari berat total seluruh bahan. Keseluruhan bahan hijauan daun yang meliputi kipahit, batang jagung, debog pisang dan rumput gajah dicacah hingga berukuran kecil dengan lebar kurang lebih 2-3 cm. Selain itu juga dilakukan pencacahan akar bambu sebagai sumber PGPR. Pencacahan dilakukan secara manual dengan menggunakan pisau yang tajam. Seluruh peserta ikut andil dalam kegiatan pencacahan ini. Pencacahan bahan hijauan dilakukan dengan tujuan agar proses pengguraian bahan pupuk organik saat prose fermentasi berlangsung lebih cepat.

\section{- Pengadukan Pupuk Kotoran sapi}

Bahan kotoran sapi yang diperoleh dari kandang ternak masih berupa bongkahan-bongkahan besar sehinnga butuh dihaluakan. Proses penghalusan dilakukan denga menggunakan cangkul. Kotoran sapi diaduk dengan cangkul sehingga menjadi lebih halus dan mudah untuk dicampur dengan bahan yang lain. 


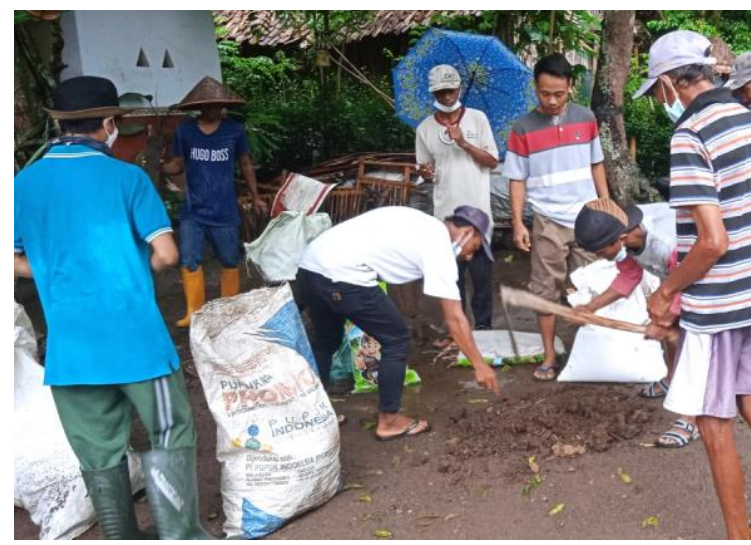

Gambar 6. Proses Pengadukan Korotan Sapi

\section{- Pengadukan Bahan Coklatan}

Bahan coklatan yang terdiri dari sekam padi, serbuk kayu, cangkang kulit kopi dan cocopeat dicampurkan menjadi satu, kemudian diaduk dengan bahan kotoran sapi dan bahan hijauan hingga merata. Pengadukan dilakukan dengan menggunakan cangkul.

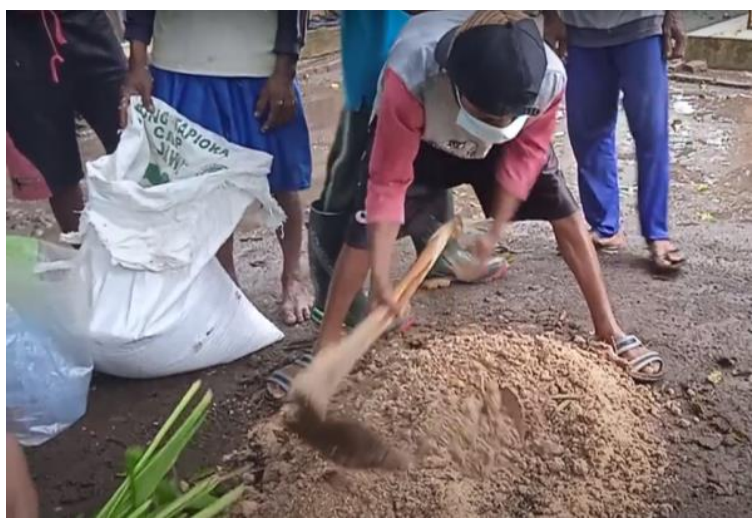

Gambar 7. Pengadukan Bahan Coklatan

\section{- Pemberian EM4 dan molase.}

Bahan EM4 mengandung bakteri yang berguna untuk mempercepat prose fermentasi bahan pupuk organik. Sementara molase berfungsi sebagai bahan energi bagi bakteri. Kebutuhan molase dan EM 4 adalah 1 liter untuk setiap $100 \mathrm{~kg}$ bahan. Pada kegiatan ini, keseluruhan bahan yang terdiri dari hijauan, coklatan dan kotoran sapi berjumlah 50kg. Sehingga dibutuhkan 500ml Molase dan EM4. Molase dan EM4 dimasukan kedalam 2 liter air pada gembor diaduk hingga tercampur sempurna, kemudian dituangkan secara merata pada campuran bahan pupuk organik.

\section{c. Pengemasan untuk Proses Fermentasi}

Bahan pupuk organik yang telah siap kemudian dimasukan kedalam polibag hitam hingga 3/4 bagian. Bagian ujung polibag kemudian diikat agar tidak ada udara yan masuk. Lakukan prosses fermentasi selama 2-3 minggu.

\subsection{Tahapan Monitoring dan Evaluasi}

Monitoring dilakukan terhadap pupuk organik yang telah dibuat. Monitoring pertama dilakukan proses fermentasi berlangsung selama 2 minggu. Tampilan pupuk terlihat sebagaimana terdapat pada Gambar 8. Beberapa bagian bahan coklatan maupun hijauan belum terdekomposisi terutama bagian batang jagung. Warna pupuk masih terlihat kecoklatan dan strukturnya masih lembek. Pada minggu kedua proses fermentasi, pupuk organik belum berhasil terbentuk. Monitoring selanjutnya dilakukan pada minggu ketiga proses fermentasi. Sebagaimana terlihat pada Gambar 17, warna pupuk sudah lebih gelap dari sebelumnya. Ditinjau dari bahan yang terdekomposisi, sebagian besar terlah terdekomposisi namun ada beberapa bagian batang pohon jagung yang belum hancur. Pada minggu ini, struktur tanah terlihat mulai remah, gembur, tidak beraroma busuk karena aktivitas mikroorganisme dalam merombak bahan organik.

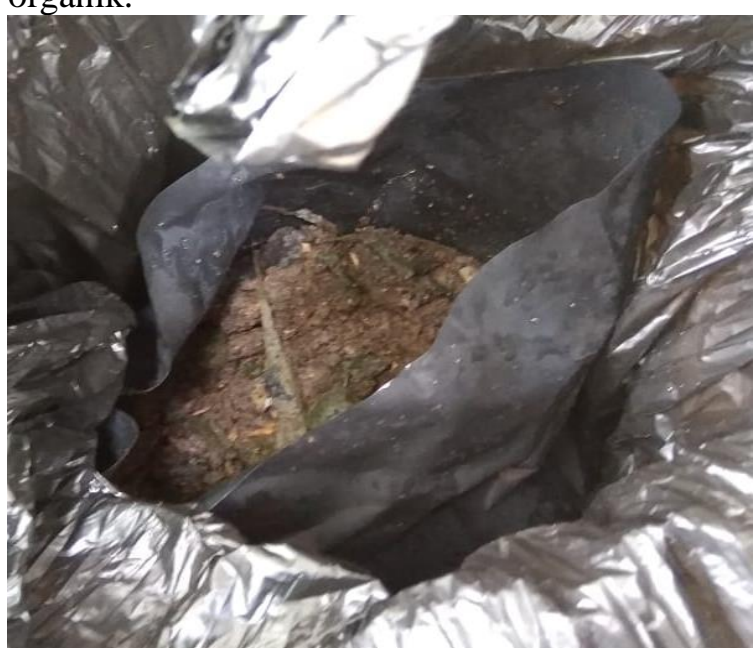




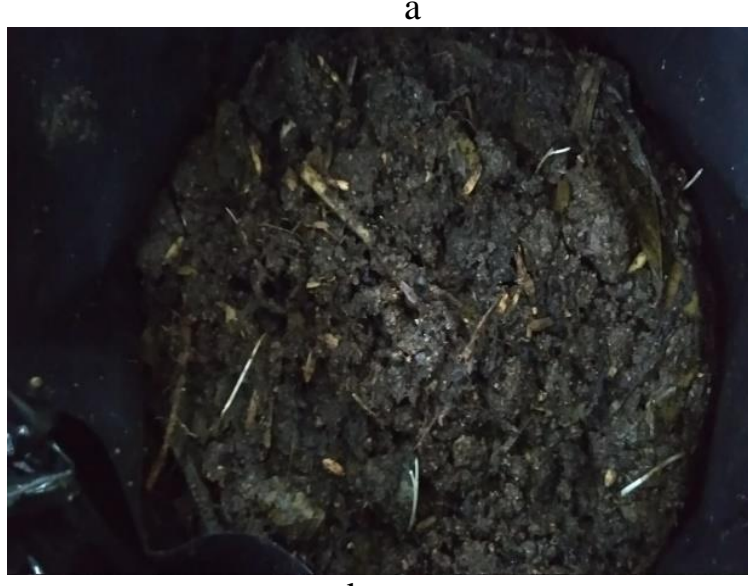

b

Gambar 8. Hasil Fermentasi Pupuk Organik setelah 2 minggu (a) dan 3 Minggu (b)

\subsection{Luaran yang dihasilkan}

a. Petunjuk Praktis Pembuatan Pupuk Organik Padat dari Kotoran Sapi

Petunjuk pembuatan Pupuk Organik Padat disusun dengan sistematis dan disajikan dalam bentuk pamflet. Hal ini memudahkan petani dan peternak dalam memahami proses pembuatan pupuk organik sehingga membantu mereka untuk lebih terampil dalam pembuatan pupuk organik.

\section{Kesimpulan}

Program pengolahan limbah kotoran sapi menjadi pupuk organik disambut baik oleh masyarakat Desa Seputih. Masyarakat Desa Seputih telah memiliki kemampuan untuk membuat produk pupuk organik padat secara mandiri. Pupuk organik hasil siap digunakan setelah proses fermentasi berlangsung lebih dari tiga minggu yang dicirikan dengan struktur tanah terlihat mulai remah, gembur, tidak beraroma busuk dan warna tanah berwarna gelap. Pemanfaatan kotoran sapi menjadi pupuk membantu memenuhi kebutuhan pupuk bagi petani sekaligus mengurangi limbah yang mencemari lingkungan tempat tinggal warga.

\section{Daftar Pustaka}

Nasution, H., Henny D. J., Ulsanna L, dan Wahyuningsih. 2017. Pemanfaatan
Limbah Cair Tahu dan Daun Gamal (Gliricidia sepium) sebagai Pupuk Organik Cair dengan Metoda Fermentasi dengan Aktivator EM4. Photon,8(1): 127-135.

Rastiyanto, E.,Sutirman, dan A. Pullaila. 2013. Pengaruh Pemberian Pupuk Organik Kotoran Kambing terhadap Pertumbuhan dan Hasil Tanaman Kailan (Brassica oleraceae. L). Buletin IKATAN, 3(2): 36-40.

Sahetapy, M.M., J. Pongoh, dan W. Tilaar. 2017. Analisis Pengaruh Beberapa Dosis Pupuk Bokashi Kotoran Ayam Terhadap Pertumbuhan dan Produksi Tiga Varietas Tomat (Solanum lycopersicum L.) Di Desa Airmadidi. Agri-Sosio Ekonomi Unsrat, 13(2): 70- 82.

Tabun, A. C., B. Ndoen, C. L. Leo Peu, J. A. Jermias, Try A. Y., dan D. A. J. Ndolu. 2017. Pemanfaatan Limbah dalam Produksi Pupuk Bokashi dan Pupuk Cair Organik di Desa Tuatuka Kecamatan Kupang Timur. Pengabdian Masyarakat, 2(2): 107115.

Trivana, L., A. Y. Pradhana. 2017. Optimalisasi Waktu Pengomposan dan Kualitas Pupuk Kandang dari Kotoran Kambing dan Debu Sabut Kelapa dengan Bioaktivator PROMI dan Orgadec. Sain Veteriner, 35(1): 136-144.

Windyasmara, L., A. Pertiwiningrum, dan L. M. Yusiati. 2012. Pengaruh Jenis Kotoran Ternak sebagai Substrat dengan Penambahan Serasah Daun Jati (Tectona Grandis) terhadap Karakteristik Biogas pada Proses Fermentasi. Peternakan, 36(1): 40-47. 